\title{
RANDOM AND FUZZY MEASURE OF UNPREDICTABLE CONSTRUCTION WORKS
}

\begin{abstract}
J. KONIOR ${ }^{1}$
Supplementing well recognised practical models of project and construction management, based on probabilistic and fuzzy events may make possible to transfer the weight of the change and extra orders assessment from the qualitative form to a quantitative one. This assessment, however, is naturally burdened with an immeasurable, subjective aspect. Elaboration of probability of occurrence in a construction project unforeseen building works requires application (in addition to the non-measureable, qualitative criteria) of measurable (quantitative) criteria which still appear during construction project implementation. In reimbursable engineering contracts, a random event described as an extra, supplementary building work has a random character and occurs with a specific likelihood. In lump sum contracts, on the other hand, such a random event has a fuzzy character and its occurrence is defined in a linear manner by the function of affiliation to the set of fuzzy events being identical with unforeseen events. The strive for quantitative presentation of criteria regarded by nature as qualitative and the intention to determine relations between them led to the application of the fuzzy sets theory to this issue. Their properties enable description of the unforeseen works of construction projects in an unambiguous, quantitative way.
\end{abstract}

Keywords: construction, unpredictable works, randomness, fuzziness

\section{INTRODUCTION. CERTAIN, RISKY, UNCERTAIN AND FUZZY STATES}

While performing technical inspection of buildings, experts face problems of working on the qualitative (immeasurable data) basis rather than on a quantitative one.

\footnotetext{
${ }^{1}$ PhD., Eng., Wroclaw University of Technology, Faculty of Civil Engineering, Department of Construction Methods and Management, Wybrzeże Wyspiańskiego 27, 50-370 Wrocław, Poland, e-mail: jaroslaw.konior@pwr.edu.pl
} 
The decision making theory presents a classical division of such situations that have been presented from three following points of view by originators of fuzzy sets theory [3], [12], [13], [14], [15]:

- Degree of uncertainties;

- Number of experts;

- Number of decision making phases.

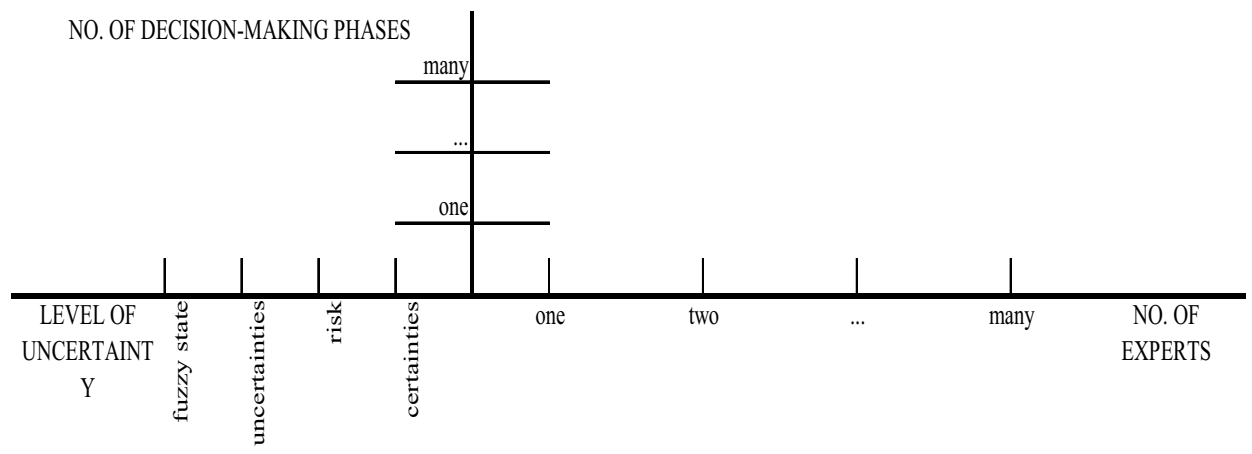

Fig. 1. Classification scheme of decision making tasks in conditions of uncertainty

In the axis 'level of uncertainty' in Figure 1, the following decisions pertaining to uncertain and fuzzy situations have been marked:

- certainties: the entire information describing the decision making process has deterministic character, which means that possibilities of decision choice are precisely known; decision making in such a case is limited to maximizing of the usefulness function in the value analysis;

- risk: the entire information describing the decision making process is probabilistic, i.e. probability distributions are easily applied; the decision making process stands for optimization of the expected value of usefulness function;

- uncertainties: even the probability distributions are unknown; the decision making relies on application of min-max strategy to ensure the best possible value of usefulness in the worst expected conditions;

- fuzzy state: uncertainties tackle not only the existence of an event appearance but its overall meaning that cannot be described by probabilistic methods.

Some other combinations are possible, e.g. by adding risk to uncertainties. 
In the axis 'number of experts' the following situations have been shown: one decision maker, two, and many. If there are more than one decision maker than they may be representative of more groups or organisations that cannot be treated as a uniform group because their interests may stay in conflict with one another by representing different points of view.

In the axis 'number of decision making phases' there are two fundamental situations: one phase and many phases. They reflect the problem in both aspects - static and dynamic.

By combining these groups of situations shown in three axes in Fig. 1 all possible states of making decision have been elaborated, e.g.: 'certainties - one decision expert - one phase of decision making process', 'risk - two experts - many decision phases', 'uncertainties - two experts - one decision phase', etc. These combinations cover all areas of decision making theories, e.g.: twoplayer games, N-player games, multiphase decision making process, etc. Unfortunately, not all of these states of making decisions are fully described by mathematical models and confirmed by practical applications. It is generally said that the further the experts go along the axis the less recognized the states of making decision process are.

To sum up, the paper presents an approach to management situation quite commonly met though difficult in construction lump - sum contracts: 'fuzziness - many experts - many phase of decision making process' [3].

\section{REASONS FOR OCCURRENCE OF UNFORESEEN CONSTRUCTION WORKS IN INVESTMENT PROCESS}

Regardless of the character of predictability of the phenomenon in question the reasons for the occurrence of the supplementary and variation (unforeseen) works were referred to as faults. The faults - whether deliberate or not - may be included in the following groups depending on the cause of their occurrence and the liability of the investment process participants [1], [4]:

- $Z_{1 j}$ - investor's faults

- $\mathrm{Z}_{2 \mathrm{j}}$ - designer's faults

- $Z_{3 j}$ - contractor's faults

- $\mathrm{Z}_{4 \mathrm{j}}-$ construction authorities faults 


\section{VARIATION WORKS AND SUPPLEMENTARY WORKS AS FUZZY EVENTS}

\subsection{FUZZY SETS AND FUZZY EVENTS}

The main notion from the theory used in the paper is the fuzzy set notion [3], [12], [13], [14], [15]:. The fuzzy set may be defined in this most straightforward manner: A fuzzy set is such a set A whose elements $\mathrm{x}$ are characterized by the lack of a sharp limit between the affiliation and nonaffiliation of $\mathrm{x}$ to the set $\mathrm{A}$. The degree of affiliation of an element $\mathrm{x}$ to the fuzzy set $\mathrm{A}$ is described by a function $\mu_{\mathrm{A}}(\mathrm{x})$ known as the affiliation function. Function $\mu_{\mathrm{A}}(\mathrm{x})$ accepts values from the interval $[0,1]$, while:

$$
\begin{array}{ll}
\mu_{A}(x)=0 & \text { denotes the absence of any affiliation of } x \text { to } A, \\
\mu_{A}(x)=1 & \text { denotes full affiliation of } x \text { to } A .
\end{array}
$$

The fuzzy set A in a certain space (in this paper it is a range of events that result in the occurrence of the supplementary and the variation building works) $\mathrm{X}=\{\mathrm{x}\}$, expressed as $\mathrm{A} \subseteq \mathrm{X}$, is referred to as a set of pairs:

$$
\mathrm{A}=\left\{\left(\mu_{\mathrm{A}}(\mathrm{x}), \mathrm{x}\right)\right\}, \forall \mathrm{x} \in \mathrm{X} .
$$

Thus, two main fuzzy sets can be distinguished in the discussion that follows:

- a fuzzy set of events (faults) that cause unforeseen building works $A \subseteq Z$ :

$$
\mathrm{Z}=\left\{\left(\mu_{\mathrm{Z}}(\mathrm{z}), \mathrm{z}\right)\right\}, \forall \mathrm{z} \in \mathrm{Z} ;
$$

- a fuzzy set of the supplementary and the variation building works $\mathrm{B} \subseteq \mathrm{U}$ :

$$
\mathrm{U}=\{(\mu \mathrm{U}(\mathrm{u}), \mathrm{u})\}, \forall \mathrm{u} \in \mathrm{U} \text {. }
$$

In the paper, the approach proposed by Zadeh [14], [15] was used, who defined probabilities of occurrence of fuzzy events in the form of real numbers from the interval $[0,1]$. Thus, the probability of a fuzzy event, which generates a fault leading to the occurrence of the unforeseen building works during the project implementation, was defined as follows:

$$
\mathrm{P}(\mathrm{Z})=\sum_{\mathrm{i}=1}^{\mathrm{n}} \mathrm{p}\left(\mathrm{z}_{\mathrm{i}}\right) \mu_{\mathrm{zi}}\left(\mathrm{z}_{\mathrm{i}}\right) \text {, when } \mathrm{Z}=\left\{\mathrm{z}_{\mathrm{i}}\right\}=\left\{\mathrm{z}_{1}, \mathrm{z}_{2}, \ldots, \mathrm{z}_{\mathrm{n}}\right\}
$$


For the fault assumed as an event equivalent, the need for the execution of the variation and the supplementary works as a fuzzy event is a probability that can be expressed with an identical relation:

$$
\mathrm{P}(\mathrm{U})=\sum_{\mathrm{j}=1}^{\mathrm{m}} \mathrm{p}\left(\mathrm{u}_{\mathrm{j}}\right) \mu_{\mathrm{uj}}\left(\mathrm{u}_{\mathrm{j}}\right) \text {, when } \mathrm{U}=\left\{\mathrm{u}_{\mathrm{j}}\right\}=\left\{\mathrm{u}_{1}, \mathrm{u}_{2}, \ldots, \mathrm{u}_{\mathrm{m}}\right\}
$$

\subsection{FUZZY RELATIONS AND THEIR BASIC PROPERTIES}

Conventional (non-fuzzy) sets enabled adequate expression of certain precisely defined properties of theoretical and observed conditions. The relation (non-fuzzy) enabled adequate expression of precisely defined interdependence between variables of these conditions (if such dependences existed) [10].

The problem appeared when it was necessary to express interdependences that were defined not very precisely, e.g.: What is the impact (cause) of faults on the need to execute variation and supplementary building works? The notion of a fuzzy relation was used to define the problem and record parameters of the phenomenon. Each pair of arguments $(\mathrm{x}, \mathrm{y}) \Leftrightarrow(\mathrm{z}, \mathrm{u})$ was assigned with a degree (measure) of affiliation that expresses intensity of occurrence of relations between $\mathrm{Z}$ and $\mathrm{U}$, that is how $\mathrm{Z}$ depends on $\mathrm{U}$, i.e. what interdependences (correlations) occur between them. It was assumed that $\mathrm{Z}$ and $\mathrm{U}$ as unsharp sets, determined under conditions of fuzziness, may be in a certain relation with one another. As a result, the fuzzy relation was defined as follows [2]:

A two-argument fuzzy relation $R$ between two sets $Z=\{z\}$ and $U=\{u\}$ is a relation defined as a fuzzy set determined on the Cartesian product $\mathrm{Z} \times \mathrm{U}$ :

$$
\mathrm{R} \subseteq \mathrm{Z} \times \mathrm{U}=\{(\mathrm{z}, \mathrm{u}): \mathrm{z} \in \mathrm{Z}, \mathrm{u} \in \mathrm{U}\}
$$

it is thus a set of pairs:

$$
\mathrm{R}=\left\{\left(\mu_{\mathrm{R}}(\mathrm{z}, \mathrm{u}),(\mathrm{z}, \mathrm{u})\right)\right\}, \forall \mathrm{z} \in \mathrm{Z}, \forall \mathrm{u} \in \mathrm{U}
$$


where $\mu_{\mathrm{R}}: \mathrm{Z} \times \mathrm{U} \rightarrow[0,1]$ is an affiliation function of the fuzzy relation $\mathrm{R}$ attributing each pair $(\mathrm{z}, \mathrm{u})$ : $\mathrm{z} \in \mathrm{Z} \mathrm{u} \in \mathrm{U}$, with its affiliation degree $\mu_{\mathrm{R}}(\mathrm{z}, \mathrm{u}) \in[0,1]$, being a measure of intensity of the fuzzy relation $\mathrm{R}$ between $\mathrm{Z}$ and $\mathrm{U}$.

The fuzzy relation may therefore be presented as follows:

$$
\mathrm{R}=\sum_{\mathrm{z}, \mathrm{u}} \mu \mathrm{R}(\mathrm{z}, \mathrm{u}) /(\mathrm{z}, \mathrm{u})
$$

The main fuzzy relation, defined at a general level in this paper, is the relation pertaining to generating faults $\mathrm{Z}$ and the occurrence of unforeseen works $\mathrm{U}$ during the construction execution. A measure of relation between $Z$ and $U$ are values equivalent to the affiliation degree $\mu_{R} \Leftrightarrow \mu_{Z, u}$. The fuzzy relation $\mathrm{R}=\mathrm{Z} \times \mathrm{U}$ defined in this manner was presented as a fuzzy relation matrix.

The matrix components, representing fuzzy relations between $\mathrm{Z}$ and $\mathrm{U}$ inform us about the degree to which the fuzzy event of making design, contractor's and other faults (expressed by the intensity of occurrence of these faults) has an impact on the scale (degree) of the supplementary and variation works in relation to the basic (foreseen) works.

For all fuzzy relations $\mathrm{R} \subseteq \mathrm{Z} \times \mathrm{U}$ the following parameters were determined in fuzzy relation matrix $\mathrm{R}=\mathrm{Z} \times \mathrm{U}$ :

- domain of a fuzzy function $\mathrm{R} \subseteq \mathrm{Z} \times \mathrm{U}$, referred to as the first projection of the fuzzy function and marked as 'dom R':

$$
\mu_{\text {domR }}(\mathrm{z})=\bigvee_{\mathrm{z} \in \mathrm{Z}} \mu_{\mathrm{R}}(\mathrm{z}, \mathrm{u}) \Leftrightarrow \bigvee_{\mathrm{i}=1}^{\mathrm{n}} \mathrm{z}_{\mathrm{i}}=\max \left\{\mathrm{z}_{1}, \mathrm{z}_{2}, \ldots, \mathrm{z}_{\mathrm{n}}\right\}
$$

- range of fuzzy relation $\mathrm{R} \subseteq \mathrm{Z} \times \mathrm{U}$, referred to as the second projection of the fuzzy relation and marked as 'ran R':

$$
\mu_{\operatorname{ranR}}(\mathrm{u})=\bigvee_{\mathrm{u} \in \mathrm{U}} \mu_{\mathrm{R}}(\mathrm{z}, \mathrm{u}) \Leftrightarrow \bigvee_{\mathrm{j}=1}^{\mathrm{m}} \mathrm{u}_{\mathrm{j}}=\max \left\{\mathrm{u}_{1}, \mathrm{u}_{2}, \ldots, \mathrm{u}_{\mathrm{m}}\right\}
$$

- height of fuzzy relation $\mathrm{R} \subseteq \mathrm{Z} \times \mathrm{U}$, referred to as the global projection of the fuzzy relation and marked as $h(\mathrm{R})$ 


$$
\mathrm{h}(\mathrm{R})=\mathrm{Z}_{\mathrm{z} \in \mathrm{Z}} \mu_{\mathrm{domR}}(\mathrm{z})=\underset{\mathrm{u} \in \mathrm{U}}{\mathrm{V}} \mu_{\operatorname{ranR}}(\mathrm{u})=\mathrm{Z}_{\mathrm{z} \in \mathrm{Z}} \mathrm{U}_{\mathrm{u} \in \mathrm{U}} \mu_{\mathrm{R}}(\mathrm{z}, \mathrm{u})
$$

and, when $h(R)=1$ then the fuzzy relation is normal and, if $h(R)<1$ it is subnormal.

\section{CAUSE - EFFECT FUZZY MODEL IN LUMP-SUM CONSTRUCTION CONTRACTS}

Thus, a decision was made to make an attempt on a practical solution (while still treating sets $U$ and $\mathrm{Z}$ as fuzzy ones), that involved application of the so called fuzzy relation equations that are particularly useful in diagnostics of conditional phenomena, i.e. cause - effect relations [9], [11].

A preliminary assumption was made that in the process of the practical assessment of the occurrence of the variation and the supplementary building works, the making of a fault represents the cause $(Z)$ and the need for bearing additional, unforeseen project works represents the effect (U) in the analysis and the control of costs that progress in an increasing manner in the construction project.

There were 19 similar projects - industrial green field plants, approximately 10.000 square meters area each, with around $10 \mathrm{mln} €$ budget - selected, investigated and researched to describe relation between project 25 faults impacts and affiliation of 10 typical unforeseen construction works of investigated lump-sum projects [5].

Typical unforeseen (extra, additional) project activities in construction have been defined as fuzzy events as follows:

- $\mathrm{U}_{1}$ - change of functional program

- $\mathrm{U}_{2}$ - application for new permits

- $\mathrm{U}_{3}$ - updated arrangements with local authorities

- $\mathrm{U}_{4}$ - amended design works

- $\mathrm{U}_{5}$ - extra ground and compound works

- $\mathrm{U}_{6}$ - extra works of building structure

- $\mathrm{U}_{7}-$ extra installation works

- $\mathrm{U}_{8}-$ extra finishing works

- $\mathrm{U}_{9}$ - extra works of building surroundings

- $\mathrm{U}_{10}$ - delays and difficulties with commissioning and maintenance 
All fuzzy relations $R \subseteq Z \times U$ corresponding to 25 indicated faults $Z_{\mathrm{ij}}$ in 4 groups and 10 typical unforeseen construction activities $U_{j}$ have been determined in fuzzy relation matrix $R=Z \times U$ presented in the table 1.

Table 1. Matrix of fuzzy relation $\mathrm{R}=\mathrm{Z} \times \mathrm{U}$ for 10 typical projects unforeseen works and 25 of their selected faults

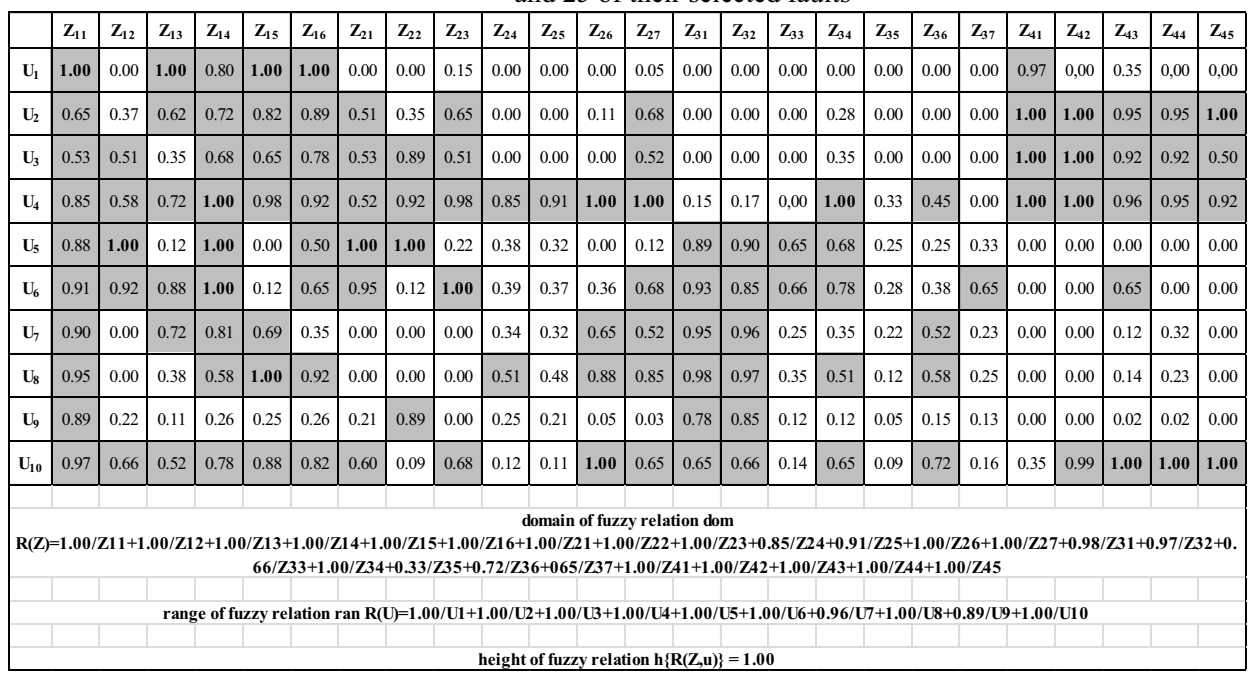

It was possible to calculate the range, the domain and the height of the fuzzy relations $\mathrm{R} \subseteq \mathrm{Z} \times \mathrm{U}$ as quantitative values. There are three main conclusions from elaborating the relations $\mathrm{R} \subseteq \mathrm{Z} \times \mathrm{U}$ in fuzzy sets categories [8]:

- around 3/4 out of $250 \mathrm{Z}_{\mathrm{ij}}$ and $\mathrm{U}_{\mathrm{j}}$ relations pair are linked with each other in " $\mathrm{i}$ " columns, half of them with R over 0.5 which indicates significant alliances

- there is only one fuzzy category of fault $Z_{11}$ (a poorly constructed business plan and an underestimated project budget) which has had an overall and strong $(\mathrm{R}>0.5)$ impact on fuzzy unforeseen works $\mathrm{U}_{1-10}$ in all 19 investigated projects,

- the height $h(R)$ of the tested fuzzy relations $R \subseteq Z \times U$ is getting to normal (1) not only as one maximum in the relation matrix but appears in 25 cases $\left(10 \%\right.$ of $Z_{\mathrm{ij}}$ and $\mathrm{U}_{\mathrm{j}}$ relations) 


\section{FUZZINESS VERSUS RANDOMNESS}

\subsection{FUZZINESS VERSUS RANDOMNESS IN LITERATURE}

It shall be stressed, that the author used a slightly simplified approach that attributed a fuzzy number to the probability of fuzzy events, as opposed to the approach presented by Yager [12], [13] according to which the probabilities are fuzzy events. It is important that no differences between the notion of fuzziness and randomness were taken into consideration in the paper. It was only assumed that despite the fact that these two phenomena are different and described in a different way, they may (as two types of uncertainty) occur together [4], [7], [8].

The main rules of the fuzzy sets calculus shall be supplemented with the following comments: The fact that the affiliation function of the fuzzy set assumes values from the interval $[0,1]$ may prompt a hasty conclusion that fuzziness is some hidden type of randomness, and therefore the fuzzy sets theory is in fact nothing new when compared with the probability theory. Differences between the fuzziness and the randomness concern, however, both their nature and formal differences between the probabilistic calculation and the calculations in fuzzy sets. The nature of these phenomena is related to the issue of uncertainty of the randomness and the fuzziness type. Thus, in the case of the randomness, the event is precisely determined, whereas its occurrence is uncertain. The randomness may, therefore, be identified with uncertainty as regards the affiliation or non-affiliation of an element to the set (in the paper: faults in the unit price contracts). A different situation pertains to the fuzziness, as it concerns the same degree of affiliation of an element to the set (in the paper: faults in the lump sum contracts). Thus, an event is not strictly defined in this case. Such events, analysed in the paper, are the faults that result in the possibility of occurrence of unforeseen works reflected in the schedule of works for a construction project. The author is of a view that their nature combines both the fuzziness and the randomness [4], [8].

\subsection{FUZZINESS VERSUS RANDOMNESS IN CONSTRUCTION WORKS}

The occurrence during the construction execution phase of works that were unforeseen at the project preparation stage (known in the building industry as variation or supplementary works) is a common element of the investment process [5], [6].

These undesirable, unforeseen events have their origins already during the tender procedure and the creation of the form of the construction works contract between the Employer and the Contractor, 
regardless of whether the project is privately funded or represents a public procurement. The wellknown and commonly used engineering contracts, such as the FIDIC, the VOB, the NEC or the JCT provide a choice of various systems for the funding and accounting of the building works covered by the contract. With regard to the possibility of occurrence of the unforeseen works, the varied forms of contracts may be divided in two groups A and B:

A. Contracts based on reimbursable costs (target fee), which by their nature provide for the occurrence of the supplementary and the variation works that are subject of the asbuilt accounting between the employer and the contractor. Here, the random event described as an unforeseen building work has a random character and occurs with a specific, determinable probability.

B. Lump sum (fixed fee) contracts according to which the need for the performance of the variation and the supplementary works may arise only during the project execution phase. In this case, the random event defined as an unforeseen building work has a fuzzy character and its occurrence is defined by a linear function of affiliation in the set of fuzzy events identical with the unforeseen events.

In Poland and Central Europe (also in case of 48 researched construction projects) the group b) of lump sum engineering contracts takes an overwhelming majority over the group a), especially in the area of non-public procurement. Therefore, it is so crucial to apply fuzzy sets models with their fuzzy tools which makes possible to convert qualitative inputs of construction projects into quantitative outputs priceless for construction enterprises cycle of their quality improvements $[5],[6]$.

\section{SUMMARY}

The approach presented in the paper - the methodological assumptions and the fuzzy sets method to measure unpredictable construction works - should be treated as an exploratory work. Thus, it is an attempt at the recognition of the mechanism of the reasons and effects of phenomena, which an Employer, a Contractor and a Contract Engineer meet in the management of construction enterprises. This assessment, however, is naturally burdened with an immeasurable, subjective aspect. Supplementing well recognised practical models of project and construction management, based on probabilistic and fuzzy events makes possible to transfer the weight of the variation and the supplementary orders assessment from the qualitative form to a quantitative one. This applies 
mainly to the lump-sum, fix-fee construction projects where unforeseen works appear as fuzzy events during the projects execution.

The intention of the author is to carry out further work on project management and construction procedures using the approach described above. Such method has been laid out, explained and proved in the paper.

\section{REFERENCES}

1. Al-Humaidi H. M.,Hadipriono T. F., "Fuzzy logic approach to model delays in construction projects using rotational fuzzy fault tree models", Civil Engineering and Environmental Systems 2010, pp. 329-351.

2. Chan K. Y., Kwong C. K., Dillon T. S., Fung K. Y., "An intelligent fuzzy regression approach for affective product design that captures nonlinearity and fuzziness", Journal of Engineering 2011, pp. 523-542.

3. Kacprzyk J., "Fuzzy sets in the system analysis", PWN, Warsaw 1986.

4. Konior J. "Fuzzy relations in supplementary and variation building works", Management of the investment process in construction. 6th All Polish Seminar BUDIN 2004, Wrocław 2004.

5. Konior J., "Quality Management Systems in PM Group Poland", Project Management Group procedures, PM Group, Ireland, 2003-2015

6. Kosko B., "Fuzziness vs. probability”, International Journal of General Systems 1990, pp. 211-240.

7. Marcinkowska E., "Decision making problems in the planning of buildings and construction processes", Wrocław University of Technology. Monographs. Wrocław 1986.

8. Kapliński O., "Analytical methods and models in the building project engineering", PAN, KILiW, Warsaw 2007, pp. 249-284.

9. Nasirzadeh F, Afshar A., Khanzadi M., Howick S., "Integrating system dynamics and fuzzy logic modelling for construction risk management", Construction Management and Economics 2008, pp. 1197-1212.

10. Perfilieva I., Gottwald S., "Solvability and approximate solvability of fuzzy relation equations", International Journal of General Systems 2003, pp. 361-372.

11. Tah J. H. M., Carr V., “A proposal for construction project risk assessment using fuzzy logic”, Construction Management and Economics 2000, pp. 491-500.

12. Yager R. R. “A note on probabilities of fuzzy events”, Information and Science; vol. 18. Iona College 1979

13. Yager R. R. "On the fuzzy cardinality of a fuzzy set”, International Journal of General Systems 2007, pp. 191206.

14. Zadeh L. "Fuzzy sets and systems", System theory. Politechnic Press. Red. J. Fox. Berkeley 1965.

15. Zadeh L. "Fuzzy sets and systems", International Journal of General Systems 1990, pp. 129-138.

\section{LIST OF FIGURES AND TABLES:}

Fig. 1. Classification scheme of decision making tasks in conditions of uncertainty

Rys. 1. Schemat klasyfikacji podejmowania decyzji w warunkach niepewności

Tab. 1. Matrix of fuzzy relation $\mathrm{R}=\mathrm{Z} \times \mathrm{U}$ for 10 typical projects unforeseen works and 25 of their selected faults

Tab. 1. Macierz relacji rozmytych $\mathrm{R}=\mathrm{Z} \times \mathrm{U}$ dla 10 typowych nieprzewidzianych robót budowlanych i ich

25 wybranych błędów przyczynowych 


\section{MIARA PRAWDOPODOBNA I ROZMYTA ROBÓT NIEPRZEWIDZIANYCH W BUDOWNICTWIE}

Slowa kluczowe: budownictwo, roboty nieprzewidziane, przypadkowość, rozmytość

\section{STRESZCZENIE}

Szacując prawdopodobieństwo wystąpienia w przedsięwzięciu budowlanym zamiennych lub dodatkowych robót budowlanych stosuje się - oprócz kryteriów niemierzalnych (jakościowych) - kryteria mierzalne (ilościowe) wyrażone w analizie przepływu środków finansowych w czasie realizacji przedsięwzięcia budowlanego.

W kontraktach inżynierskich powykonawczych zdarzenie losowe określone jako nieprzewidziana robota budowlana ma charakter losowy i występuje $\mathrm{z}$ określonym prawdopodobieństwem: w kontraktach ryczałtowych natomiast takie zdarzenie losowe ma charakter rozmyty i jego występowanie jest określone liniowo funkcją przynależności do zbioru zdarzeń rozmytych tożsamych z nieprzewidzianymi. Dążenie do ilościowego ujęcia kryteriów z natury uchodzących za jakościowe i chęć wyznaczenia panujących między nimi relacji, doprowadziło do spojrzenia na zagadnienie w kategoriach zbiorów rozmytych jako pochodną ujęcia probabilistycznego. Ich właściwości dają możliwość opisania nieprzewidzianych - zamiennych i dodatkowych - robót budowlanych w jednoznacznym aspekcie ilościowym.

\section{ROZMYTOŚĆ A PRZYPADKOWOŚĆ W BUDOWLANYM PROCESIE INWESTYCYJNYM}

Pojawianie się na etapie realizacji obiektu budowlanego robót nieprzewidzianych w fazie przygotowania inwestycji, zwanych w budownictwie robotami zamiennymi lub dodatkowymi, jest powszechnie występującym elementem procesu inwestycyjnego.

Natura występowania tych niepożądanych, nieprzewidzianych zdarzeń bierze swój początek już w trakcie prowadzonej procedury przetargowej i kształtowania formy umowy na wykonanie robót budowlanych pomiędzy zamawiającym a wykonawcą i to bez względu na to czy przedsięwzięcie jest finansowane ze środków prywatnych, czy też jest zamówieniem publicznym. Znane, powszechnie stosowane wzory kontraktów inżynierskich jak FIDIC, VOB, NEC, JCT przewidują wiele systemów finansowania i rozliczania robót budowlanych będących przedmiotem umowy. Z punktu widzenia możliwości wystąpienia robót nieprzewidzianych, zróżnicowane formy umów można podzielić na dwie grupy A i B:

A. kontrakty oparte na kosztach zwracalnych (,reimbursable”, „target fee”), które od początku w swojej istocie zakładają wystąpienie robót dodatkowych i zamiennych, będących przedmiotem rozliczeń powykonawczych pomiędzy zamawiającym a wykonawcą; tu zdarzenie losowe opisane jako nieprzewidziana robota budowlana ma charakter losowy i występuje z określonym, wyznaczalnym prawdopodobieństwem;

B. kontrakty ryczałtowe („lump-sum”, fixed fee”), według których konieczność wykonania robót zamiennych i dodatkowych może pojawić się jedynie na etapie realizacji inwestycji; tu zdarzenie losowe opisane jako nieprzewidziana robota budowlana ma charakter rozmyty i jej występowanie jest określone liniowo funkcją przynależności do zbioru zdarzeń rozmytych tożsamych z nieprzewidzianymi. 
Rozpoznanie przyczyn powodujących pojawianie się konieczności wykonania robót nieprzewidzianych w fazie projektowania inwestycji jest zasadniczym wskazaniem do usprawnienia znanych modeli racjonalnego zarządzania przedsięwzięciem budowlanym i minimalizacji ryzyka wystąpienia robót zamiennych i dodatkowych.

\section{PRZYCZYNY WYSTĘPOWANIA NIEPRZEWIDZIANYCH ROBÓT BUDOWLANYCH}

Niezależnie od charakteru przewidywalności opisywanego zjawiska, przyczyny wystąpienia budowlanych robót dodatkowych i zamiennych (nieprzewidzianych) nazwano błędami. Błędy te - zamierzone lub niezamierzone - w zależności od źródła ich występowania i odpowiedzialności uczestników procesu inwestycyjnego można sklasyfikować w następujące grupy:

- $\mathrm{Z}_{\mathrm{lj}}$ - błędy inwestora

- $Z_{2 j}$ - błędy projektanta

- $Z_{3 j}-$ błędy wykonawcy

- $\quad Z_{4 j}$ - błędy administracji budowlanej

\section{ROZMYTY MODEL PRZYCZYNOWO - SKUTKOWY. PODSUMOWANIE}

Przyjęto założenie, że grupę błędów przyczynowych $Z_{1-4, j}$ i grupę robót nieprzewidzianych, które te błędy powodują $U_{j}$ można oznaczyć jako dwa zbiory rozmyte $Z$ i U pozostające ze sobą w relacji rozmytej i dające się opisać równaniami rozmytymi $\mathrm{R} \subseteq \mathrm{Z} \times \mathrm{U}$ i macierzą relacji rozmytych $\mathrm{R}=\mathrm{Z} \times \mathrm{U}$.

19 podobnych przedsięwzięć budowlanych - nowo wznoszonych, przemysłowych zakładów o powierzchni około $10.000 \mathrm{~m} 2$ każdy, z budżetem inwestycyjnym około $40 \mathrm{mln}$ złotych - wyodrębniono jako próbę badawczą do wyznaczenia siły rozmytych powiązań błędów przyczynowych i robót dodatkowych, które te błędy wywołały w analizowanych zadaniach inwestycyjnych.

Wyznaczono typowe, najczęściej występujące nieprzewidziane, dodatkowe (uzupełniające lub zamienne) aktywności w budowlanym procesie inwestycyjnym, opisane jako zdarzenia rozmyte:

- $\mathrm{U}_{1}$ - zmiana programu funkcjonalnego

- $\mathrm{U}_{2}$ - wystąpienie o pozwolenia budowlane zamienne

- $\mathrm{U}_{3}$ - aktualizacja uzgodnień z organami administracji budowlanej

- $\mathrm{U}_{4}$ - prace projektowe zamienne i uzupełniające

- $\mathrm{U}_{5}$ - dodatkowe roboty ziemne i placu budowy

- $\mathrm{U}_{6}$ - dodatkowe roboty konstrukcyjne

- $\mathrm{U}_{7}$ - dodatkowe roboty instalacyjne

- $\mathrm{U}_{8}$ - dodatkowe roboty wykończeniowe

- $\quad \mathrm{U}_{9}$ - dodatkowe roboty terenów przyległych

- $\quad \mathrm{U}_{10}$ - opóźnienia w odbiorach i rozpoczęciu użytkowania obiektu budowlanego

Wszystkie wyznaczone relacje rozmyte $\mathrm{R} \subseteq \mathrm{Z} \times \mathrm{U}$, korespondujące $\mathrm{z}$ określonymi błędami przyczynowymi $\mathrm{Z}_{\mathrm{ij}}$ w 4 grupach i 10 typowymi dodatkowymi działaniami w zadaniach inwestycyjnych zostały wyliczone i przedstawione $\mathrm{w}$ macierzy relacji rozmytych $\mathrm{R}=\mathrm{Z} \times \mathrm{U}$. 
W ten sposób stało się możliwe obliczenie zakresu, domeny i wysokości tak określonych relacji rozmytych jako wartości liczbowych, mierzalnych. Z analizy wyprowadzono trzy główne wnioski:

- $\quad$ około $3 / 4$ z 250 relacji $Z_{\mathrm{ij}}$ i $\mathrm{U}_{\mathrm{j}}$ jest parami powiązana ze sobą, a połowa $\mathrm{z}$ nich wskazuje na silne rozmyte związki relacyjne $\mathrm{z}$ wartością $\mathrm{R}$ ponad 0.5 ;

- tylko jedna kategoria błędów przyczynowych $Z_{11}$ (wadliwie skonstruowany biznes plan inwestycji i niedoszacowany budżet zadania inwestycyjnego) wykazuje całkowity i silny $(\mathrm{R}>0.5)$ wpływ na wszystkie nieprzewidziane działania inwestycyjne $\mathrm{U}_{1-10} \mathrm{~W} 19$ analizowanych przedsięwzięciach budowlanych;

- wysokość badanych relacji rozmytych $h(R)$ dochodzi do wartości normalych (pełnych jak w zdarzeniach determistycznych), równych 1 aż w 25 przypadkach (10\% relacji $\mathrm{R} \subseteq \mathrm{Z} \times \mathrm{U})$. 